\title{
LANDSCAPE PEMIKIRAN ABU AL-A'LA AL-MAWDUDI (1903-1979) TENTANG KONSEP NEGARA ISLAM
}

\author{
Abu Dzarrin al-Hamidy \\ Dosen Tetap Fakultas Syariah IAIN Sunan Ampel Surabaya
}

\begin{abstract}
Sosok Mawdudi hadir dengan membawa semangat idealisme yang begitu kuat dalam segenap pemikiran maupun gerakangerakannya. Semangat untuk melakukan rintisan besar-besaran di Negara Pakistan-suatu negara di mana ia tinggal-tersebut didasarkan pada confidence yang kuat yang terpatri dalam kepribadiannya. la berpandangan, bahwa konsep segala sesuatu ada dalam norma ajaran agama Islam sehingga tidak perlu mengadopsi ajaran-ajaran di luar Islam termasuk dari Barat. Konsep negara Islam adalah salah satu aspek yang menjadi pusat perhatiannya. Baginya, Sistem kenegaraan Islam tidak dapat disebut "demokrasi" karena dalam sistem demokrasi kekuasaan negara itu sepenuhnya di tangan "rakyat", dalam arti bahwa suatu undang-undang atau hukum itu diundangkan, diubah, dan diganti semata-mata berdasarkan pendapat dan keinginan rakyat. Sistem politik Islam lebih tepat disebut "teokrasi" yang pengertian teokrasi di sini sama sekali berbeda dengan teokrasi di Eropa. Teokrasi Eropa adalah suatu sistem di mana kekuasaan negara berada pada kelas tertentu, kelas pendeta, yang dengan atas nama Tuhan menyusun dan mengundangkan suatu undang-undang atau hukum kepada rakyat sesuai dengan keinginan dan kepentingan kelas itu dan memerintah negara dengan berlindung di belakang "hukumhukum Tuhan". Sedangkan teokrasi dalam Islam, kekuasaan Tuhan itu berada di tangan umat Islam yang melaksanakannya sesuai dengan apa yang telah disampaikan oleh al-Qur'an dan Sunnah Nabi. Atau mungkin dapat diciptakan istilah baru dalam hal ini, yaitu "teodemokrasi" karena dalam sistem ini umat Islam memiliki kedaulatan rakyat yang terbatas.
\end{abstract}

Kata kunci: Konsep negara Islam, demokrasi, teokrasi, teodemokrasi 


\section{Pendahuluan}

Ada dua aspirasi politik umat Islam saat itu di India. Segolongan menginginkan terwujudnya suatu negara bagi umat Islam terpisah dari anak benua India sementara segolongan yang lain tetap menginginkan negara India terdiri atas umat Islam dan umat Hindu. ${ }^{1}$

Setelah Pakistan berdiri secara resmi sebagai negara merdeka bagi umat Islam India-tepatnya pada tanggal 15 Agustus 1947 di mana satu hari sebelumnya yaitu tanggal 14 Agustus 1947 pemerintah Inggris telah membuka dengan resmi Dewan Konstitusi Pakistan ${ }^{2}$-Mawdudi melihat adanya fenomena, bahwa para pendiri Pakistan cenderung inkonsistensi dalam melaksanakan ajaran-ajaran Islam dalam konteks kehidupan berbangsa dan bernegara yang note bene didirikan atas nama Islam. Hal ini mendorong Mawdudi tampil sebagai pejuang yang gigih dan berupaya menjadikan Islam sebagai pandangan hidup (world view) dan sumber konstitusi negara ini. ${ }^{3}$

Mawdudi dalam melihat Islam bukan hanya sebagai suatu ajaran normatif tetapi juga sebagai ideologi yang komprehensif. Di dalamnya terkandung sistem ekonomi Islam, sistem politik Islam, sistem hukum Islam, dan lain-lain. Pemikiran Mawdudi ini, paling tidak, menyadarkan umat Islam saat itu yang acap kali mengadopsi gagasan-gagasan dari Barat. ${ }^{4}$

Dari uraian di atas, permasalahan yang menarik untuk dikaji dalam tulisan ini adalah siapa sebenarnya sosok Mawdudi itu?, dan apa serta bagaimana ide-ide pembaharuannya khususnya yang berkaitan dengan konsep negara Islam?

'Departemen Agama Republik Indonesia (DEPAG RI), Ensiklopedi Islam di Indonesia, jil. 2 (Jakarta: Proyek Peningkatan Prasarana dan Sarana Perguruan Tinggi Agama, 1992/1993), 733.

2Harun Nasution, Pembaharuan dalam Islam, Sejarah Pemikiran dan Gerakan, cet 9 (Jakarta: PT Bulan Bintang. 1992), 199.

${ }^{3}$ DEPAG RI, Ensiklopedi..., 733.

${ }^{4}$ Erwin I.J. Rosenthal, Islam in the Modern National State (London : Camridge University Press, 1965), 139. 


\section{Sekilas Biografi Abu al-A'la al-Mawdudi ${ }^{5}$}

Mawdudi lahir pada 3 Rajab 1321 H./25 September 1903 M. di Aurangabad, suatu kota terkenal di kesultanan Hyderabad (sekarang ini Andhra Prades di India Selatan) Deccan (sekarang Maharashtra). Dia dilahirkan dari keluarga terhormat (sharif), yakni keluarga tokoh Muslim Delhi di India Utara yang bermukim di Deccan. Selain itu, geneologi nenek moyangnya dari garis ayah memiliki sisilah yang sambung dengan Nabi Muhammad SAW. Inilah sebabnya, Mawdudi memakai nama gelar Sayyid. ${ }^{6}$

Keluarganya mempunyai tradisi yang lama sebagai pemimpin agama karena banyak dari nenek moyang Mawdudi adalah shaykh-shaykh tarekat sufi yang terkenal. Salah seorang dari shaykh-shykh yang terkenal itu adalah shaykh yang dari namanya itu-Abu al-A'la-mengambil nama keluarga, yaitu Khawajah Qutb al-Din Mawdudi kemudian pindah ke anak benua India dari Chisht pada akhir abad ke-9 H./abad ke-15 M. Orang pertama yang sekaligus sebagai kepala atau pemimpin keluarga besar Mawdudi yang tiba di anak benua India itu adalah orang yang namanya sama dengan Abu al-A'la, yaitu Abu al-A'la Mawdudi (w. $935 \mathrm{H}) .^{7}$

${ }^{5}$ Nama "Abu al-A'la" pernah menimbulkan masalah karena berarti ayah (dari) Yang Maha Tinggi (YMT), sedangkan YMT adalah salah satu atribut Tuhan. Arti yang demikian ini memang terdapat dalam sejumlah ayat al-Qur'an. Mawdudi kemudian dalam pembelaannya mengutip dua ayat al-Qur'an yang menyebutkan bahwa atribut al-A'/a dan al-A'lawna (kata jamak dari al$A^{\prime \prime}$ (a), juga diberikan kepada manusia, yakni kepada Nabi Musa as dan kepada orang-orang yang beriman. Lihat Munawir Sjadzali, Islam dan Tata Negara (Ajaran, Sejarah, dan Pemikiran), edisi 5 (Jakarta: UI Press, 1993), 158.

'Maryam Jameelah, Who is Maudoodi?, edisi 3 (Lahore: Mohammad Yusuf Khan \& Sons, 1983), I; Seyyed Vali Reza Nasr, "Mawdudi, Sayyid Abu al-A'la," The Oxford Encyclopedia of the Modern Islamic World, vol. 3, ed. John L. Esposito, et. al. (New York: Oxford University Press, 1995), 72; idem, "Mawdudi dan Jama at-I Islamu: Asal-usul, Teori, dan Praktik Kebangkitan Islam," dalam Para Perintis Zaman Baru Islam, cet. 2, ed. Ali Rahnema, ter. Ilyas Hasan (Bandung: Mizan, 1996), 283; Khurshid Ahamd dan Zafar Ishaq Ansari, "Mawlana Sayyid Abul A'la Mawdudi, an Introduction to His Vision of Islam and Islamic Revival," dalam Islamic Prespectives Studies in Honour of Mawlana Sayyid Abul A'la Mawdudi, ed. K. Ahmad dan Z.I. Ansari (Jeddah: The Islamic Foundation U.K. in Association with Sandi Publishing House, t.th.), 360.

${ }^{7}$ K. Ahmad dan Z.I. Ansari, "Mawlana Sayyid ...", 360; Munawir Sjadzali, Islam dan Tata Negara ..., 158.

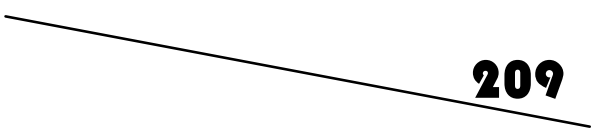


Ayah Mawdudi, Sayyid Ahmad Hasan (1855-1919 M.) adalah seorang pengacara yang sebelumnya studi hukumnya ia tempuh di Allahabad dan kemudian bermukim di Deccan lalu pindah ke Hyderabad. Dari sinilah ia menjadi pengikut tasawuf yang setia ${ }^{8}$ sehingga timbul semangat puritanisnya untuk menciptakan lingkungan yang sangat religius dan zuhud bagi pendidikan anakanaknya. Ahmad Hasan berupaya keras mendidik dan membesarkan anaknya dalam kultur sharif. Dia mendidik mereka dengan sistem pendidikan klasik. Dalam sistem ini tidak ada mata pelajaran bahasa Inggris dan modern. Mereka diajar bahasa Arab, Persia, dan Urdu (bahasa Ibu) di rumah, juga membaca teks sastra dan agama selama bertahun-tahun. Mawdudi kemudian menjadi ahli dalam bahasa Arab pada usia yang sangat relatif muda. Dia menguasai bahasa Arab dengan sangat baik. Terjemahan al-Mar'ah al-Jadidah (Wanita Modern) karya Qasim Amin dari bahasa Arab ke bahasa Urdu adalah bukti riil kemampuannya dalam bidang bahasa Arab. Upaya menterjemahkan itu dilakukan pada saat ia berusia 14 (empat belas) tahun. ${ }^{9}$

Mawdudi adalah anak yang paling bungsu dari tiga bersaudara. Setelah memperoleh pendidikan dasar di bawah bimbingan ayahnya sendiri, tiga tahun sebelumnya, yakni pada saat ia berusia sebelas tahun ia masuk Madrasah Fawqaniyyah, yaitu sekolah menengah yang menggabungkan sistem pendidikan Barat modern dengan sistem pendidikan Islam tradisional. Dan untuk pertama kalinya, ia mendapatkan pelajaran ilmu kimia, ilmu alam, matematika, dan sebagainya. ${ }^{10}$

Setelah menyelesaikan dengan sukses pendidikan menengahnya, Mawdudi melanjutkan ke jenjang

\footnotetext{
${ }^{8}$ Dan ia tinggalkan profesi sebelumnya sebagai pengacara mengingat dalam prakteknya ia setiap kali harus melakukan hal-hal yang bertentangan dengan hati nuraninya yang memegang teguh kemurnian moral dan akhlak Islami. Juga ia sudah tidak respek dengan pola hidup rekan seprofesinya yang menurutnya kebarat-baratan dan tidak Islami. Dengan demikian, ia mempunyai waktu yang cukup untuk mengajar dan mendidik anak-anaknya, termasuk Mawdudi. Lihat Munawir Sjadzali, ibid.

${ }^{9}$ S.V. Reza Nasr, "Mawdudi ..., "72.

${ }^{10}$ Munawir Sjadzali, Islam dan Tata Negara, I58- I59.
} 
pendidikan/perguruan tinggi, yaitu di Dar al-'Ulum Hyderabad. Pada saat ia tengah menempuh pendidikan tingginya, tepatnya lima tahun kemudian pada saat ia berusia enam belas tahun, ayahnya sakit dan kemudian meninggal dunia. Oleh karena itu, ia tidak dapat melanjutkannya secara formal. Namun demikian, ia tetap bersemangat untuk belajar secara mandiri dalam rangka memenuhi minat intelektualnya sekalipun dilakukan di luar lembaga-lembaga pendidikan reguler. ${ }^{11}$ Hal inilah yang mendorongnya bekerja untuk mencari nafkah hidup di salah satu penerbitan Islam di Delhi. ${ }^{12}$ Sementara pada waktu luangnya, ia belajar secara otodidak dan rajin membaca buku-buku sastra Arab, tafsir, mantik, dan filsafat yang ditopang oleh kemampuan bahasanya: Arab, Inggris, Persia, dan Urdu sehingga ia mampu memperdalam pengetahuannya secara mandiri. ${ }^{13}$ Setelah keadaan ekonominya mulai lumayan, ia menyempatkan diri memperdalam berbagai cabang ilmu agama di bawah bimbingan-bimbingan ulama-ulama yang ahli dalam cabang-cabang ilmu tersebut secara sorogan (tutorial), yaitu dengan mendatangi guru-guru untuk mendapatkan pelajaran secara khusus. ${ }^{14}$

Pada tahun 1918, Mawdudi memulai karirnya di bidang kewartawanan atau jurnalistik dengan cara membantu kakaknya,

"K. Ahmad dan Z.I. Ansari, "Mawlana Sayyid ...," 360-36I; A. Mukti Ali, Alam Pikiran Islam, 238.

${ }^{12}$ Dalam hal ini, Mawdudi sempat melukiskan suka dukanya ketika itu dengan mengatakan: "Harihari berlalu dengan pelan, dengan membawa secerah cahaya lilin harapan, melangkah setapak demi setapak. Mulailah realita kehidupan yang pahit membuka selubung kepahitannya. Pengalaman satu tahun setengah memberikan pelajaran berharga, bahwa tidak ada jalan bagi manusia selain bekerja keras, berjuang demi sesuap nasi. Allah telah mengaruniakan kepandaian menulis kepadaku yang didapat melalui bacaan dan telaah, dari sini aku memutuskan untuk menjadikan pena sebagai sarana mencari rizki." Lihat Mustafa Muhammad Tahhan, Model Kepemimpinan dalam Islam (Studi Tokoh Pergerakan Islam Kontemporer), cet. I, ter. Mustholah Maufur (Jakarta: Robbani Press, 1997), 171.

13Munawir Sjadzali, Islam dan Tata Negara, I58-159; lihat juga Wilfred Cautwell Smith, Modern Islam in India (a Social Analysis) (New Delhi: Usha Publication, 1979), I76; Hamid Enayat, Modern Islamic Political Thought (London: The Macmillan Press, 1982), I0 I.

${ }^{14}$ Sjadzali, Islam dan ..., I 59.

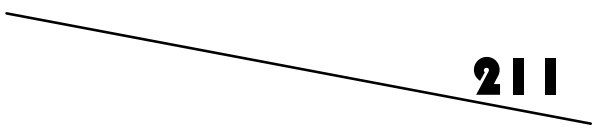


Abu al-Khayr, mengasuh majalah al-Madinah di Bijnur. ${ }^{15}$ Dua tahun kemudian, yaitu tahun 1920, pada usia 17 tahun, ia telah diangkat menjadi editor surat kabar Mingguan Taj, sebuah surat kabar berbahasa Urdu yang pro-Partai Kongres yang terbit di Jabalpore, suatu kota di propinsi yang sekarang ini dinamakan Madhya Pradesh, India. Lalu pada akhir tahun 1920, Mawdudi balik ke Delhi. Di sini dia berkenalan dengan pemimpin penting gerakan Khilafat seperti Muhammad Ali. Bersama M. Ali ini, Mawdudi bekerja sama menerbitkan koran nasionalis, Hamdard, tapi tidak berlangsung lama. Selama periode inilah pandangan politiknya kian menjadi religius. Dia bergabung dengan gerakan protes, Tahrik-I Hijrat, suatu gerakan/organisasi oposisi terhadap pemerintah Inggris atas India yang mendorong kaum Muslim India untuk meninggalkan India, yang merupakan kawasan dar alharb (abode of war) dan hijrah secara massal ke Afganistan sebagai kawasan dar al-Islam (abode of Islam), sebuah negara yang diperintah oleh orang Muslim. ${ }^{16}$

Pada tahun 1921, Mawdudi berkenalan dengan pemimpin Jamiyat-i Ulama-i Hind (Masyarakat Ulama India), Mawlana Kifayatullah dan Ahmad Sa'id. Ulama ini terkesan melihat bakat Mawdudi. Kemudian Mawdudi diundang untuk jadi editor koran resmi mereka, Muslim (1921-1923), hingga kemudian nama koran tersebut diganti menjadi al-Jam'iyat (1924-1928). Di bawah kepemimpinannya, al-Jam'iyat menjadi surat kabar terkemuka umat Muslim India. ${ }^{17}$

\footnotetext{
${ }^{15}$ S.V. Reza Nash, "Mawdudi...," I03. Bijnur adalah suatu kawasan di bawah jajahan Inggris. Oleh karena profesi kewartawanan di daerah jajahan Inggris itu sangat diperlukan penguasaan bahasa Inggris, Mawdudi "terpaksa" untuk lebih mendalami sekaligus "mengasah" bahasa Inggrisnya, lihat Sjadzali, Islam ..., I59.

${ }^{16}$ S.V. Reza Nasr, "Mawdudi dan ...," I04; A. Mukti Ali, Alam Pikiran ..., 239.

${ }^{17}$ S.V Reza Nasr, "Mawdudi, Sayyid ...," 72; Idem, "Mawdudi dan ...," I04; K. Ahmad dan Z.I. Ansari, "Mawdudi Sayyid ....," 36I. Penyebutan kedua periode masing-masing surat kabar di atas merupakan pendapat sekaligus sintesa penulis yang didasarkan atas ketiga sumber tadi. Kalau Ahmad dan Ansari menyebutkan: ... Muslim (I921-1923) dan ....al-Jam'iyat(1925-1928), berarti ada distorsi waktu satu tahun, yaitu tahun 1924. Jadi, periode yang benar menurut hemat penulis dengan didasarkan atas dua sumber yang disebut pertama adalah seperti yang tertulis di atas.
} 
Perlu diketahui pula, selama tahun 1920 hingga 1928 Mawdudi juga menerjemahkan empat buah buku, satu dari bahasa Arab dan yang ketiga lainnya dari bahasa Inggris. Ia juga menulis karya monumentalnya al-Jihad fi al-Islam (Religious War in Islam). Karya ini dinilai sangat komprehensif dan sistematis dalam uraian-uraiannya mengenai hukum Islam tentang perang dan damai. Pertama isi buku itu ditulis secara bersambung dalam alJam iyat pada tahun 1927. dan secara formal diterbitkan pada tahun 1930. Buku ini mendapat pujian dari Muhammad Iqbal (w. 1938 M.) dan Mawlana Muhammad 'Ali Jawhar (w. 1931 M).

Setelah meninggalkan Al-Jam'iyat pada tahun 1928, Mawdudi pindah ke Hyderabad. Sejak itu ia mencurahkan segenap perhatian untuk memimpin umat menuju keselamatan politik dan agama. Di Hyderabad ini, ia banyak menulis dalam berbagai soal. Ia menyelesaikan sejumlah terjemahan buku tafsir dan filsafat dari bahasa Arab, menulis sejarah Hyderabad, dan menyiapkan teks studi Islam atas perintah pemerintah Nizam. Yang paling penting di antaranya adalah mukaddimah Islamnya, Risalah-yi Diniyat yang kemudian diterjemahkan dalam bahasa Inggris dengan judul Thowards Understanding Islam. Di Hyderabad inilah, untuk pertama kalinya religiusitasnya lebih tampak dalam dirinya. Dia "kembali" ke Islam dengan membawa pandangan baru yang religius. Hal ini ia dapatkan setelah banyak membaca soal-soal penting politik. ${ }^{18}$

Pada tahun 1932, Mawdudi mulai menerbitkan Tarjuman alQur'an, sebuah jurnal yang selama 40 (empat puluh tahun) berikutnya menjadi media terpenting bagi pandanganpandangannya. Mawdudi tahu, bahwa tulisan saja tak mungkin berpengaruh pada peristiwa politik yang memperlihatkan derap yang cepat dalam sejarah India periode itu. Upaya intelektualnya harus dibarengi upaya suatu organisasi yang berdasarkan pada gagasannya. Kesimpulan inilah yang menyebabkannya pindah ke Punjab pada tahun 1938 untuk memimpin Dar al-Islam, sebuah

18S.V. Reza Nasr, "Mawdudi ...," 73 ; Idem, "Mawdudi dan ...," 106.

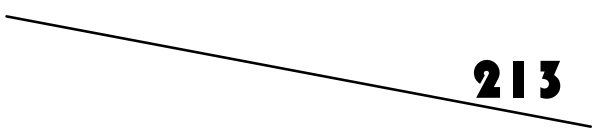


pusat riset akademi dan proyek pendidikan yang pada mulanya diprakarsai oleh Muhammad Iqbal (w. 1938), penyair sekaligus pemikir tersohor Punjab di Pathankut, sebuah dusun kecil di Punjab. Di Dar al-Islam inilah, Mawdudi membangun model komunitas Islam yang diharapkannya dapat melahirkan pembaharuan Islam besar-besaran di India. ${ }^{19}$

Namun Mawdudi nampaknya tidak bisa melepaskan dari aktifitas politiknya sambil tetap memikirkan kelanjutan Dar alIslam. Mawdudi senantiasa tetap terlibat dalam perdebatan di seputar Gerakan Pakistan antara Liga Muslim dan orang Muslim pendukung Partai Kongres (all Indian Congress Party). Dalam perjuangan Mawdudi selanjutnya, karena begitu sibuknya dengan politik, ia tidak bisa lagi memperhatikan proyek Dar al-Islam-nya. Dan pada tahun 1939 kemudian, ia melakukan aktivitas politiknya secara lebih langsung di Lahore. Di Lahore inilah, sekitar tahun 1940, timbul gagasan perlunya partai baru yang akan mewujudkan cita-citanya dalam upayanya mengembangkan suatu gerakan yang lebih komprehensif. Pada bulan Agustus 1941, Mawdudi bersama sejumlah aktivis Muslim dan ulama muda mendirikan Jama at-I Islami (Islamic Party). Segera setelah berdiri, Jama at-i pindah markas ke Pathankot di mana Mawdudi dan kolega serta pengikutnya mengembangkan struktur partai, sikap politik, ideologi, dan rencana aksi. Dari Pathankut, Jama at-i mengorganisasi di seluruh India. Jama at-i berkembang cepat dan

\footnotetext{
${ }^{19}$ Ibid. Satu tahun sebelumnya, yakni pada tahun 1937, telah terjadi kontak antara M. Iqbal dan Mawdudi. M. Iqbal sebagai pemrakarsa menyurati Mawdudi yang isinya menwarkan pindah ke Punjab dan bekerja sama dengannya dalam karya riset raksasa rekonstruksi dan kodifikasi Yurisprudensi Islam. Korespondensi in berlanjut dengan dua kali pertemuan antara kedua tokoh itu. Akhirnya diputuskan, bahwa Mawdudi harus pindah ke Punjab dan memimpin suatu lembaga riset Islam, Dar al-Islam, Mawdudi meninggalkan Hyderabad dan tinggal di Punjab pada bulan Maret 1938. "Tapi celakanya," demikian Mawdudi bergumam, "Beliau (lqbal) tengah tepat berada di ujung usianya. Tepat sebulan kemudian beliau menghembuskan nafasnya yang terakhir dan saya ditinggalkan sendirian untuk menanggung tugas yang mahaberat ini, yang telah kami putuskan untuk kami lakukan bersama." Lihat biografi Mawdudi ynag ditulis oleh Khurshid Ahmad dalam Sayyid Abu al-Al la Mawdudi, The Islamic Law and Constitution, edisi 6, ter, dan ed. Khurshid Ahmad (Lahore : Islamic Publications LTD., 1977), 387-388.
} 
cukup ektensif sehingga berpengaruh langsung pada jalannya berbagai peristiwa di India. ${ }^{20}$

Akhirnya, karena gangguan kesehatan, ia meninggal dunia pada tanggal 23 September 1979 di salah satu rumah sakit di New York, Amerika Serikat. ${ }^{21}$ Ia wafat pada saat masih menjabat sebagai anggota Komite Pendiri Rabitat al-'A<lam al-Islami, yang berpusat di Makkah dan anggota Akademi Riset tentang hukum Islam di Madinah. ${ }^{22}$

\section{Pokok-pokok Pikiran Abu al-A la Mawdudi tentang Kenegaraan}

Pembaharuan-pembaharuan yang dilakukan oleh Mawdudi, pada hakikatnya didasarkan atas visinya terhadap Islam yang berangkat dari doktrin "Tauhid". ${ }^{23}$ Konsepsinya tentang tauhid inilah yang ia tekankan berulang-ulang, dan mungkin melebihi dari pengarang-pengarang lainnya. Ia menganggap bahwa konsepsi tauhid itu merupakan suatu konsep yang benar dan orisinil sebagaimana diterangkan oleh semua nabi dan rasul Allah. Menurut Mawdudi kalimat "la ilaha illa Allah" adalah merupakan pernyataan yang hanya mengakui dengan kukuh tentang ke-Esaan Sang Pencipta yang selanjutnya berimplikasi secara lebih jauh dari pada sekedar pengertian lafalnya. Yaitu adanya ke-Esaan Tuhan sebagai Pencipta bukan hanya sebagai satu-satunya sasaran penyembahan, tetapi ia juga menerangkan tentang tidak adanya sesuatu yang menyerupai Tuhan sebagai Yang Maha Kuasa, Yang Maha Pengatur. Sebenarnya hanya Tuhanlah yang mempunyai hak untuk memberikan perintah yang menuntut manusia untuk supaya beribadat dan berbakti kepadaNya serta menuntut ketaatan manusia secara total. Walaupun begitu, Tuhan begitu santun untuk senantiasa memberikan kebebasan kepada manusia. Manusia boleh memilih taat kepadaNya atau sebaliknya. Oleh

\footnotetext{
${ }^{20}$ Reza Nasr, “Mawdudi, Sayyid ...," 74 ; Idem, "Mawdudi dan ...," I07- 108.

${ }^{21}$ Sjadzali, Islam dan Tata ..., I 58.

${ }^{22}$ Ahmad dan Ansari, "Mawdudi Sayyid..., 364-365; A. Mukti Ali, Alam Pikiran..., 243.

${ }^{23}$ James P. Piscatori, Islam in a World of Nation State (Cambridge: Cambridge University Press, 1988), 105.
}

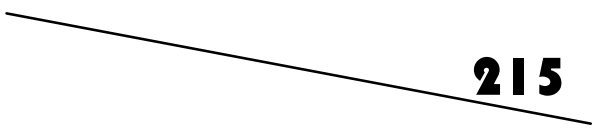


karena itu, berbakti dan beribadah kepada Tuhan bukan merupakan pemaksaan melainkan sebuah pengabdian yang tulus, yang tidak dibuat-buat, yang secara sukarela ketundukan manusia terhadap petunjuk-petunjuk Tuhan. ${ }^{24}$

Selanjutnya, dalam kaitannya dengan konsep negara Islamnya, Mawdudi menuangkan gagasan-gagasannya, baik mengenai Islam secara umum, maupun teori kenegaraannya, disosialisasikannya selain melalui majalah Tarjuman al-Qur'an, juga lewat ceramah-ceramah yang naskahnya kemudian diterbitkan. Juga ia lakukan dengan menulis risalah-risalah serta buku-buku. Menurut Munawir Sjadzali, Mawdudi termasuk dari sekian banyak pemikir politik Islam yang menyajikan konsep kenegaraan paling lengkap dari rinci. Dari sekian banyak buku atau karyakaryanya yang lain, selain buku pertamanya al-jihad fi al-Islam juga terdapat enam risalah dan satu buku yang berkaitan dengan gagasannya tentang kenegaraan. Enam risalah tersebut adalah: (1) Teori Politik Islam; (2) Metode Revolusi Islam; (3) Hukum Islam dan Cara Pelaksanaannya; (4) Kodifikasi Konstitusi Islam; (5) Hakhak Golongan Dhimmi dalam Negara Islam; dan (6) Prinsip-prinsip Dasar bagi Negara Islam. Adapun karya tulis yang berbentuk buku, antara lain berjudul Pemerintah Islam. ${ }^{25}$

\section{1) Dasar Pemikiran Mawdudi tentang Konsep Kenegaraan}

Paling tidak, ada tiga landasan keyakinan yang mendasari pemikiran Mawdudi tentang kenegaraan menurut Islam, yaitu :

a. Islam adalah suatu agama yang paripurna, lengkap dengan petunjuk untuk mengatur semua segi kehidupan manusia, termasuk kehidupan politik, dalam arti bahwa di dalam Islam terdapat pula sistem politik. Untuk itu, dalam bernegara umat Islam tidak perlu atau bahkan dilarang meniru sistem Barat.

\footnotetext{
${ }^{24}$ Selengkapnya baca Sayyid Abu al-A'la al-Mawdudi, The Islamic Law, 120-132; Idem, "Ajranajaran al-Qur'an tentang Ekonomi dan Politik," dalam Esensi al-Qur'an (Filsafat, Politik, Ekonomi, Etika), cet. 8, penyunting M.M. Syarif, ter. Ahmad Muslim (Bandung, Mizan, 1997), 84-87; Idem, Khilafah dan Kerajaan, 87; A. Mukti Ali, Alam Pikiran Islam, 243-244.

${ }^{25}$ Munawir Sjadzali, Islami dan Tata Negara, 165.
}

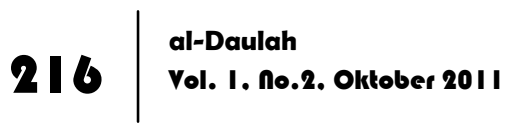


Cukup kembali kepada sistem Islam dengan menunjuk kepada pola politik masa al-Khulafa' al-Rashidun sebagai model atau contoh sistem kenegaraan menurut Islam. ${ }^{26}$

b. Kekuasaan tertinggi yang dalam istilah politik modern disebut kedaulatan adalah pada Allah. Sedangkan umat manusia hanyalah pelaksana-pelaksana (mandataris) kedaulatan Allah sebagai khalifah-khalifahNya di bumi. Dengan demikian, tidak dapat dibenarkan gagasan "kedaulatan rakyat." Dan sebagai pelaksana "kedaulatan Allah" umat manusia atau negara harus tunduk pada hukum-hukum sebagaimana yang tercantum dalam al-Qur'an dan Sunnah Nabi. Sedangkan yang dimaksud khalifah-khalifah Allah yang berwenang melaksanakan kedaulatan Allah itu adalah terbatas pada umat atau orang-orang (laki-laki dan perempuan) Islam. ${ }^{27}$

c. Sistem politik Islam adalah suatu sistem universal dan tidak mengenal batas-batas atau ikatan-ikatan geografis, bahasa, dan kebangsaan..$^{28}$

${ }^{26}$ Lihat Mawdudi, The Islamic Law, I 19.

${ }^{27}$ Ibid, I3 I dan 139. Menurut Mawdudi, kekuasaan tertinggi terletak pada "kedaulatan Tuhan", ini merupakan konsekuensi logis dari sebuah negara ideologi. Lihat Tim Penyusun Pustaka-Azet Jakarta, Leksikon Islam, jilid 2 (Jakarta: PT Puztazet Perkasa, 1988), 46I -464. Amin Rais dalam komentarnya mengatakan, bahwa teori politik Islam seperti yang dikembangkan oleh Mawdudi di atas, bila ditinjau dari kaca mata teori politik modern atau teori politik sekular dinilai unik atau bahkan kelihatan "ganjil". Keunikan atau keganjilannya terletak pada konsep dasar yang menegaskan bahwa "kedaulatan (souverenitas) itu ada di tangan Tuhan" bukan di tangan manusia atau rakyat. Argumentasi Mawdudi nampaknya cukup logis juga, yakni ia menilai katakata "kedaulatan rakyat" sering kali menjadi "kata-kata kosong" karena partisipasi rakyat dalam kebanyakan negara demokrasi hanyalah dilakukan empat atau lima tahun sekali dalam bentuk pemilu. Sedangkan kendali pemerintahan sesungguhnya berada di tangan sekelompok kecil penguasa yang menentukan seluruh kebijaksanaan dasar negara. Sekelompok penguasa itu bertindak atas nama rakyat, sekalipun sebagian pikiran dan tenaga yang mereka kerahkan bukan untuk rakyat tetapi hanyalah untuk melestarikan kekuasaan yang mereka pegang dan untuk mengamankan vested interest mereka sendiri. Lihat M. Amin Rais dalam kata pengantarnya dalam Mawdudi, Khilafah dan Kerajaan, 19-20.

${ }^{28}$ Mawdudi, The Islamic Law, 139-140; Idem, Khilafah dan Kerajaan, 88-89. Paradigma tentang tiga landasan di atas, juga telah dikemukakan oleh Munawir Sjadzali dan penulis sepakat degannya. Lihat Munawir S. Islam dan Tata Negara, 166

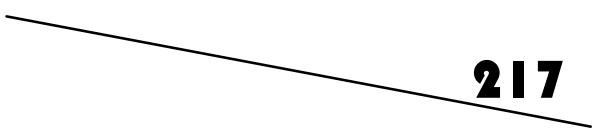




\section{2) Konsep Negara Islam}

Atas dasar tiga landasan keyakinan di atas, maka lahirlah suatu konsep kenegaraan Islam yang pokok-pokoknya adalah sebagai berikut :

a. Sistem kenegaraan Islam tidak dapat disebut "demokrasi" karena dalam sistem demokrasi kekuasaan negara itu sepenuhnya di tangan "rakyat", dalam arti bahwa suatu undang-undang atau hukum itu diundangkan, diubah, dan diganti semata-mata berdasarkan pendapat dan keinginan rakyat. Sistem politik Islam lebih tepat disebut "teokrasi" yang pengertian teokrasi di sini sama sekali berbeda dengan teokrasi di Eropa. Teokrasi Eropa adalah suatu sistem di mana kekuasaan negara berada pada kelas tertentu, kelas pendeta, yang dengan atas nama Tuhan menyusun dan mengundangkan suatu undang-undang atau hukum kepada rakyat sesuai dengan keinginan dan kepentingan kelas itu dan memerintah negara dengan berlindung di belakang "hukumhukum Tuhan". Sedangkan teokrasi dalam Islam, kekuasaan Tuhan itu berada di tangan umat Islam yang melaksanakannya sesuai dengan apa yang telah disampaikan oleh al-Qur'an dan Sunnah Nabi. Atau mungkin dapat diciptakan istilah baru dalam hal ini, yaitu "teodemokrasi" 29 karena dalam sistem ini umat Islam memiliki kedaulatan rakyat yang terbatas. ${ }^{30}$ Dalam kaitan ini, ada baiknya dikutip secara lengkap pokok pikiran Mawdudi mengenai teori kedaulatan Tuhan sampai tawaran term baru yang diajukannya;

\footnotetext{
${ }^{29}$ Menurut Taufik Adnan Amal dengan merujuk pada bukunya Aziz Ahmad yang berjudul "slamic and Demoicracy" hal. 33, bahwa istilah "teodemokrasi" ini bukanlah penemuan baru yang diperkenalkan Mawdudi. Istilah ini terlebih dahulu dikemukakan oleh Umar Hayat Malik dalam perdebatan di Majelis Konstituante Pakistan pada tahun 1949. Namun harus diakui, bahwa istilah tersebut mulai populer di tangan Mawdudi yang juga disosialisasikannya. Lihat Taufik Adnan Amal, Islamic dan Tantangan Modernitas (Studi atas Pemikiran Hukum Fazluar Rahman), cet. 5 (Bandung : Mizan, 1994), 61

${ }^{30}$ Lihat Abu al-A la Mawdudi, The Islamic Law, 133 ; Bandingkan dengan Munawir Sjadzali, Islamic dan Tata Negara, I66-167 ; Taufik Adnan Amal, Islam dan Tantangan Modernitas, 60-6I.
} 
A more apt name for the Islamic polity would be the "kongdom of God" which is discribed in English as a "theocracy." But Islamic theocracy is something altogether different from the theocracy of which Europe had a bitter experience wherein a priestly class, sharply marked off from the rest of the population, exercises unchecked domination and enforces laws of its own making in the name of God, thus virtually imposing its own divinity and godhod upon the common people. Such a system of government is satanic rather than divine. Contrary to this, the theocracy built up by Islam is not ruled by any particular religious class but by whole community of Muslims including the rank and file. The entire Muslim population runs the state in accordance with the Book of God and the practice of His prophet. If I were permitted to coin a new term, I would describe this system of government as a "theo-democracy," that is to say a divine democratic government, because under it the Muslims have been given a limited popular sovereignty under the sizerainty of God. The general will of the Muslims who have also the right to depose it. ${ }^{31}$

b. Pemerintah/badan eksekutif hanya dibentuk oleh umat Islam yang sekaligus berhak untuk memecat dari jabatannya. Demikian pula, ketika menyelesaikan soal-soal kenegaraan yang tidak mendapatkan hukum yang jelas dalam syari'at Islam, harus diputuskan oleh kesepakatan umat Islam. Dalam pada itu, hak untuk menjelaskan suatu undang-undang atau untuk menafsirkan dan mengartikan suatu nash dari al-Qur'an atau Hadis, bukan hanya wewenang suatu kelas khusus atau keluarga tertentu, melainkan merupakan hak bagi tiap warga negara yang Muslim yang telah mencapai tingkat mujtahid. Dengan demikian, sistem politik Islam ini dapat disebut demokrasi. Dan perlu diingat, bila segala sesuatunya telah dibicarakan dalam nash, baik al-Qur'an, maupun Hadis, maka baik pemuka-pemuka Islam, mujtahid, cendekiawan, badan legislatif, atau bahkan seluruh umat Islam, sedunia tidak

${ }^{31}$ Mawdudi, The Islamic Law, I32-133.

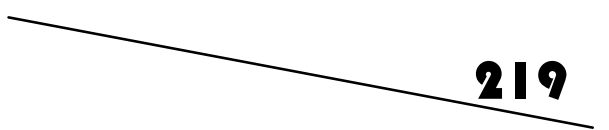


berhak mengubah sepatah-kata pun dari nash tersebut. Itulah sebabnya, sistem politik Islam dapat dinamakan "teokrasi." 32

c. Kekuasaan negara dilakukan oleh tiga lembaga atau badan, yaitu: legislatif, eksekutif, dan yudikatif dengan ketentuanketentuan sebagai berikut:

1) Kepala Negara yang juga merangkap kepala badan, yaitu ekskutif, merupakan pimpinan tertinggi negara yang bertanggungjawab kepada Allah dan kepada rakyat. Dalam melaksanakan tugasnya, dia harus selalu berkonsultasi dengan Majelis Shura (Majelis-e-Shuralthe Consultative Assembly) yang mendapat kepercayaan dari umat Islam atau yang disebut lembaga legislatif yang anggotanya dipilih melalui pemilihan, meskipun prosedur demikian tidak terdapat pada zaman al-Khulafa' alRashidun;

2) Keputusan Majelis Shura pada umumnya diambil berdasarkan suara terbanyak. Namun demikian, menurut Islam, banyaknya suara bukan merupakan satu-satunya ukuran kebenaran;

3) Kepala Negara tidak harus mengikuti pendapat Majelis yang didukung oleh suara terbanyak. Dia dapat mengambil pendapat yang didukung oleh kelompok kecil dalam majelis, atau bahkan tidak menghiraukan sama sekali pendapat-pendapat majelis, baik mayoritas, maupun minoritas. Tetapi rakyat tetap wajib mengawasi dengan jeli kebijaksanaan Kepala Negara. Dan kalau ternyata dalam memerintah dia lebih mementingkan hawa nafsunya maka mereka berhak memecatnya;

4) Untuk jabatan Kepala Negara, keanggotaan Majelis Shura, atau jabatan-jabatan lain yang penting jangan dipilih orang-orang yang mencalonkan diri untuk jabatan-jabatan tersebut atau mereka yang berupaya untuk menduduki

${ }^{32}$ lbid, |39- | 40. 
jabatan-jabatan itu. Mawdudi mendasarkan gagasannya ini pada Hadis Nabi yang intinya, bahwa beliau tidak akan menyerahkan jabatan kepada seseorang yang meminta atau berusaha mendapatkan jabatan itu. Dalam masyarakat Islam tidak ada tempat untuk pencalonan bagi pengisian jabatan-jabatan pemerintah dan tidak pula dibenarkan "kampanye pemilihan." Hal demikian adalah bertentangan dengan jiwa Islam, yakni untuk mengisi satu jabatan terdapat dua, tiga, atau empat calon yang masingmasing giat berkampanye dengan segala cara, seperti rapat, pesta, dan pawai serta penggunaan media elektronika dan cetak dengan menghambur-hamburkan uang. Dan nanti yang menang, adalah mereka yang paling pandai berbohong dan mengelabuhi rakyat, suatu hal yang dikutuk Islam;

5) Anggota Majelis Shura tidak dibenarkan terbagi ke dalam kelompok-kelompok atau partai-partai. Masing-masing anggota Majelis harus mengemukakan pendapatnya yang benar atas nama perorangan. Islam melarang anggota Majelis terbagi dalam partai-partai, dan kalau harus ada partai hanyalah satu partai, yakni partai Kepala Negara (Pemerintah);

6) Badan yudikatif atau lembaga peradilan sepenuhnya berada di luar lembaga eksekutif yang berarti harus mandiri dan terpisah dari eksekutif, oleh karena hakim, dalam tugasnya adalah melaksanakan hukum-hukum Allah atas hamba-hambaNya, bukan mewakili atau nama Kepala Negara tetapi mewakili dan atas nama Allah. Dalam ruang pengadilan kedudukan Kepala Negara adalah sama dengan orang-orang kebanyakan. Tidak dapat dibenarkan pemberian dispensasi kepada seseorang untuk tidak hadir pada sidang pengadilan hanya karena

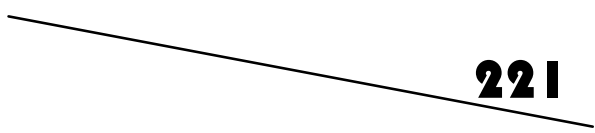


kedudukannya dalam pemerintahan atau dalam masyarakat; 33

d. Karena negara Islam adalah negara ideologis maka konsekuensinya mengenai syarat-syarat yang harus dimiliki oleh seseorang untuk dipilih menjadi Kepala Negara juga anggota Majelis Shura adalah beragama Islam, laki-laki, dewasa, sehat fisik, dan mental, warga negara terbaik, saleh, dan kuat komitmennya kepada Islam. ${ }^{34}$ Pemilihan Kepala Negara dilakukan oleh dan harus atas persetujuan seluruh umat Islam dan tidak dibenarkan seseorang memaksakan dirinya atas umat dengan kekerasan atau paksaan. Juga jabatan Kepala Negara bukan milik keluarga atau kelas tertentu. Sudah semestinya, bila pemilihan Kepala Negara diselenggarakan sesuai dengan persetujuan umat Islam tanpa kekerasan dan penipuan. ${ }^{35}$ Tentang bagaimana hal tersebut dilaksanakan, Islam tidak menetapkan metode tertentu. Mungkin saja ditempuh berbagai metode dan cara yang sesuai dengan situasi, kondisi, dan kebutuhan umat Islam, asalkan dengan cara-cara tersebut dapat diketahui siapa yang benarbenar mendapatkan kepercayaan rakyat. ${ }^{36}$ Kalau nanti dalam memerintah ternyata dia melanggar ketentuan-ketentuan syari'at atau kehilangan kepercayaan rakyat maka rakyat dapat memecatnya; ${ }^{37}$

e. Keanggotaan Majelis Shura terdiri dari warga negara yang beragama Islam, dewasa, dan laki-laki, yang terhitung salih, serta cukup terlatih untuk dapat menafsirkan dan menerapkan syari'at dan menyusun undang-undang yang tidak bertentangan dengan al-Qur'an dan Sunnah Nabi. ${ }^{38}$ Jadi wanita Islam tidak boleh duduk dalam keanggotaan Majelis

\footnotetext{
${ }^{33}$ Disarikan dari Mawdudi, Ibid, 2 I I-22 I; Munawir Sjadzali, Islam dan Tata Negara, I67- 68.

${ }^{34}$ Mawdudi, The Islamic Law, 232-234.

${ }^{35}$ lbid., 225-226.

${ }^{36} \mathrm{lbid}$., 226.

${ }^{37}$ Munawir Sjadzali, Islam ..., 169.

${ }^{38}$ Mawdudi, The Islamic Law, 230-234.
} 
Shura. ${ }^{39}$ Sedangkan tugas majelis adalah : (a) merumuskan dalam peraturan perundang-undangan mengenai petunjukpetunjuk yang secara jelas didapatkan dalam al-Qur'an dan Hadis serta peraturan pelaksanannya; (b) jika terdapat perbedaan penafsiran terhadap ayat al-Qur'an atau Hadis, atau dengan kata lain, pedoman yang ditemukan dalam kedua sumber itu memiliki kemungkinan interpretasi lebih dari satu maka Majelislah (yang berhak) memutuskan panafsiran mana yang ditetapkan yang kemudian ditempatkan dalam Kitab Undang-Undang Dasar; (c) jika tidak terdapat petunjuk yang jelas dalam al-Qur'an dan Hadis maka Majelis dapat menentukan hukum dengan tetap memperhatikan semangat atau petunjuk umum dari kedua sumber hukum itu, atau bila sudah tercantum dalam kitab-kitab fikih karya ulama yang ada maka Majelis dapat menentukan mana yang diikuti; dan (d) dalam hal sama sekali tidak dijumpai petunjuk-petunjuk dasar sekali pun dalam al-Qur'an maupun Hadis, atau suatu masalah itu tidak terdapat dalam konvensi al-Khulafa' alRashidun, Majelis dapat saja menyusun dan mengesahkan undang-undang, asalkan tidak bertentangan dengan jiwa dan semangat syari'at Islam. ${ }^{40}$

f. Dalam negara Islam terdapat dua kategori kewarganegaraan, yaitu warga negara yang beragama Islam dan warga negara bukan Islam. Warga negara yang kedua ini disebut dhimmi (rakyat yang dijamin/dilindungi eksistensinya). Dalam hal-hal keagamaan mereka diperintah oleh pemimpin-pemimpin agama mereka. Tetapi dalam bidang-bidang kehidupan yang lain mereka tunduk kepada hukum Islam. Oleh karena negara Islam adalah negara yang berdasarkan ideologi atau agama sebagaimana telah disinggung pada pembicaraan sebelumnya maka hanya mereka yang menerima ideologi atau agama Islamlah yang berhak (ikut) mengatur negara. Karenanya,

${ }^{40}$ Mawdudi, The Islamic Law, 2I 2-2 I 4.

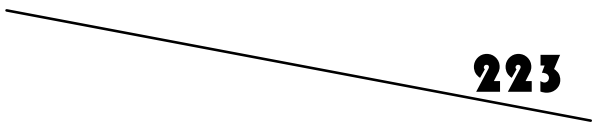


warga negara bukan Islam tidak dibenarkan menduduki jabatan-jabatan kunci dalam pemerintahan dan jabatan-jabatan yang merumuskan kebijaksanaan dan politik negara. Mereka juga dibebaskan dari wajib bela negara. ${ }^{41}$ Orang-orang bukan Islam paling tinggi hanya boleh duduk di-level semisalDPRD tingkat II yang tidak merumuskan atau memutuskan kebijaksanaan politik. ${ }^{42}$

\section{3) Komentar terhadap Konsep Negara Islamnya Abu al-A'la al- Mawdudi (sebuah Analisis Singkat)}

Mawdudi berdiri tegak dengan pemikiran-pemikirannya yang sistematis dan komprehensif selain ia juga seorang pejuang Islam yang gigih dan penulis yang produktif. Hal ini diakui bukan hanya dari kalangan tokoh-tokoh Muslim tetapi juga dari kalangan orientalis atau yang non-Muslim. Untuk ini, penulis akan mencoba menganalisisnya dan sudah tentu terbatas pada yang dirasakan "janggal". Berikut ini, analisis penulis dengan sistematika sebagai berikut :

a) Negara Masa al-Khulafa' al-Rashidun : Potret Ideal Negara

\section{Islam}

Yang bisa ditangkap dari kesan Mawdudi terhadap kehidupan kenegaraan masa al-Khulafa' al-Rashidun adalah sebuah potret negara Islam yang betul-betul ideal. Hubungan antar para pelaksana pemerintahan dan rakyat yang begitu harmonis yang itu semua diliputi oleh semangat persaudaraan yang kuat. Budaya konsultasi dan musyawarah amat menonjol dan terjaminnya kebebasan menyatakan pendapat. Akan tetapi, kesan yang demikian indah tersebut tidak cukup didukung oleh fakta sejarah.

Abu Bakr ra menduduki jabatan khalifah melalui pemilihan dalam suatu pertemuan terbuka yang dihadiri wakil-wakil dari dua komponen utama dari komunitas Islam di Madinah. Muhajirin dan Ansar, meskipun pertemuan tersebut tidak direncanakan

\footnotetext{
${ }^{41}$ Ibid., 235-242.

42Munawir Sjadzali, Islamic dan Tata Negara, 170.
} 
secara matang. Tidak demikian halnya Umar ra. Ia diangkat sebagai khalifah kedua tidak melalui pemilihan dalam suatu musyawarah terbuka. Setelah Abu Bakr ra memutuskan akan mengangkat Umar ra sebagai penggantinya, ia menyelenggarakan konsultasi tertutup dengan sejumlah sahabat Muhajirin dan Ansar, satu demi satu diminta masuk ke kamar tidur tempat ia berbaring dalam keadaan sakit. Kepada dua orang yang diminta pendapat, 'Abd al-Rahman b. 'Awf ra dan Uthman b. 'Affan ra, Abu Bakr ra berpesan agar mereka tidak menceritakan kepada orang lain tentang pembicaraannya dengan mereka itu. Hal ini berarti, pengangkatan Umar ra sebagai khalifah adalah melalui wasiat pendahulunya disertai konsultasi tertutup dan tidak ada pertemuan terbuka dari masyarakat. ${ }^{43}$

Sementara pengangkatan 'Uthman ra sebagai khalifah ketiga, juga melalui proses yang lain lagi. Umar ra dalam keadaan luka parah akibat tikaman Abu Lu'luah didesak oleh sahabat senior untuk menunjuk penggantinya. Semula ia menolak, tetapi ketika mereka datang lagi dan mendesaknya untuk kedua kalinya maka ia setuju untuk menunjuk enam orang formatur yang sepeninggalnya nanti akan memutuskan siapa pengganti ‘Umar ra. Dari sini dapat diketahui, Abu Bakr ra tidak membawa masalah siapa penggantinya ke pertemuan terbuka dengan masyarakat dan lebih dari sepuluh tahun kemudian para sahabat senior mendesak sahabat 'Umar agar menunjuk pengganti sebelum "keburu" meninggal. Hal ini mencerminkan, bahwa pola atau sistem kenegaraan Madinah saat itu masih sangat sederhana, yakni tidak merundingkan masalah suksesi itu secara terbuka. Juga enam orang yang ditunjuk oleh Umar ra sebagai tim formatur semuanya dari kelompok Muhajirin, suku Quraysh. Menurut Munawir Sjadzali, bahwa Umar ra dalam pesannya memberikan petunjuk agar paling lambat pada hari ketika sepeninggalnya sudah terpilih penggantinya atau khalifah yang baru; dan kalau lima atau empat

${ }^{43}$ Munawir Sjadzali, Islam dan Tata Negara, I7I.

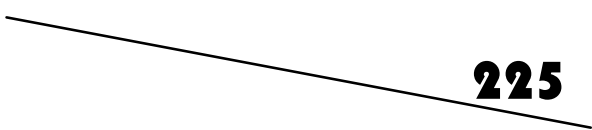


dari enam formatur itu telah bersepakat untuk menentukan seorang yang akan menjadi khalifah dari mereka, sementara terdapat satu atau dua orang yang menolaknya maka hendaknya mereka yang menolak itu dibunuh saja. Lalu Ali ra menerima kepercayaan menjadi khalifah melalui pemilihan dalam rapat terbuka yang kurang sempurna. ${ }^{44}$

Selain itu pula, tiga dari empat al-Khulafa' al-Rashidun mati terbunuh ketika masih menjabat kekhalifahannya. Semasa alKhulafa' al-Rashidun paling tidak telah terjadi tiga kali pemberontakan terhadap kekuasaan yang sah. Pertama, oleh pemberontakan dari Mesir, Basrah, dan Kufah yang berakhir dengan terbunuhnya Uthman ra; kedua, pemberontakan terhadap Ali ra yang dipimpin oleh janda Nabi saw, Siti $A<$ 'ishah yang berakibat terbunuhnya dua tokoh pemberontakan yang lain, yaitu Zubayr b. 'Awwam dan Talhah b. 'Ubaydah pada "Pertempuran Unta" (Ghazwat al-Jamal); dan ketiga, pemberontakan yang dipimpin oleh Gubernur Siria, Mu'awiyah b. Abi Sufyan, yang mencapai puncaknya pada "Pertempuran Siffin. ${ }^{45}$

Dari sini dapat dipahami, bahwa tidak adanya keseragaman dalam sistem pengangkatan empat khalifah di atas mengingat karena masih sangat sederhananya kehidupan masyarakat bernegara pada waktu itu. Yang perlu dipertanyakan sekarang adalah haruskah pada saat yang sedemikian maju peradabannya ini dan sudah mampu mengatur kehidupan bernegara dengan cara yang lebih baik masih harus mencontoh model atau pola/sistem kehidupan bernegara pada masa al-Khulafa' al-Rashidun itu yang ternyata memang masih sederhana dan belum memiliki pola atau sistem yang baku?.

${ }^{44}$ Ibid, 172.

${ }^{45}$ bid. 


\section{b) Doktrin Teodemokrasi (Souverenitas/Kedaulatan Tuhan) : Sebuah Konsekwensi Negara Ideologis}

Berbicara dalam konteks ontologis, bahwa Tuhan adalah pemegang otoritas tertinggi di dunia ini (sampai di akhirat nanti) karena Tuhan-lah yang menciptakan segala sesuatu dari alam semesta ini, nampaknya bagi umat Muslim tidak ada yang menyangkal kebenaran ungkapan tersebut yang tak lain merupakan ungkapan Mawdudi sendiri sebagaimana telah disinggung pada pembicaraan sebelumnya.

Namun perlu juga diketahui, bahwa doktrin "kedaulatan rakyat" tidak pernah diartikan untuk ingkar terhadap kedaulatan Tuhan. Menurut sejarah, doktrin kedaulatan rakyat dahulu dicanangkan untuk melawan konsep "kedaulatan raja" sebagai penguasa tertinggi dan tunggal dengan kekuasaan yang absolut. Menurut Munawir Sjadzali, Mawdudi adalah pemikir politik Islam pertama yang mempergunakan pengertian, bahwa umat manusia adalah khalifah-khalifah Allah di bumi sebagai landasan teori politik. Apa yang menjadi landasan pemikiran politiknya yaitu bahwa kedaulatan itu sepenuhnya ada pada Tuhan dan manusia sebagai khalifah-khalifah-Nya di bumi yang merupakan mandataris atau pelaksana kedaulatan Tuhan itu. Demikian pula, manusia itu harus tunduk pada ketentuan atau hukum (prinsip supremasi syari'at) yang diberikan oleh Tuhan sebagai pemilik kedaulatan tertinggi adalah tidak lain dimaksudkan untuk menjadi "landasan dasar rasionalnya", bahwa kekuasaan rakyat itu terbatas dan tidak mutlak, sebenarnya telah cukup diyakini dan didasari oleh setiap Muslim.

Sementara itu, sebagai kelanjutan dari teori Mawdudi di atas, bahwa kedudukan sebagai khalifah-khalifah itu terbatas hanya dimiliki oleh umat Islam, yaitu beraksi "bahwa tiada Tuhan selain Allah dan bahwa Muhammad adalah utusan-Nya. Kemudian ia menyandarkan gagasannya ini pada sejumlah ayat dalam alQur'an yang menyatakan bahwa umat manusia itu adalah khalifah-khalifah (penguasa-penguasa) di bumi. Di antaranya

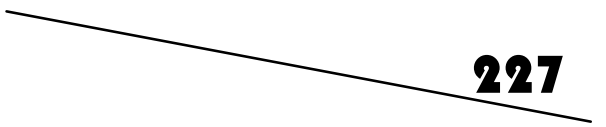


adalah ayat 62 surat al-Naml yang berarti : "Dan Ia (Allah) menjadikan kalian sebagai penguasa-penguasa di bumi." Juga ayat 165 surat al-An am yang artinya : "Ia (Allah) adalah yang menjadikan kalian penguasa-penguasa di bumi." Pada umumnya para ahli tafsir dalam mengartikan kata "kalian" dalam dua ayat tersebut adalah "umat manusia seluruhnya." Kemudian terdapat satu ayat yang lain, tepatnya ayat 55 surat al-Nur yang artinya : "Allah telah menjanjikan kepada orang-orang yang beriman di antara kalian dan yang mengerjakan perbuatan-perbuatan yang baik, maka Dia sungguh-sungguh akan menjadikan mereka penguasa." Dari ayat yang terakhir inilah, Mawdudi menyimpulkan, bahwa hanya umat Islam-lah yang berhak menyandang status khalifah-khalifah Allah itu. ${ }^{46}$

Dalam kaitan ini, menurut hemat penulis, perkataan "kalian" di atas tidak hanya ditujukan bagi yang beriman melainkan juga bagi mereka yang tidak beriman tapi berprestasi, yang berhasil mengolah dan memanfaatkan sumber daya alam yang sumber daya manusia untuk tujuan memakmurkan dunia dan meningkat kesejahteraan serta kualitas hidup manusia dan alam sekitarnya. Tipe manusia yang demikian ini, wajar bila kemudian menjadi penguasa-penguasa di bumi, tidak hanya dalam arti kekuasaan politik tetapi juga kekuasaan dalam bidang-bidang lainnya. Bukanlah Allah SWT sendiri telah menegaskannya dalam ayatayat-Nya, misalnya ayat 1 surat $a l-R a^{\prime} d$ dan ayat 53 surat al-Anfal yang intinya Tuhan tidak akan merubah keadaan suatu kaum selama mereka tidak merubah keadaannya sendiri. Dan kata "kaum" di kedua ayat itu bersifat umum dan tidak ada suatu prioritas-prioritas tertentu. Dari sini, dapat dipahami dengan jelas,

${ }^{46}$ Ibid., 173; Dari cara pandanganya, Mawdudi nampaknya tidak menyadari, bahwa kalangan masyarakat yang didekatinya sebenarnya tidak hanya religius tetapi juga sangat konservatif. Konsekuensinya, secara perlahan-lahan mulai terbenam ke dalam sikap konservatisme. Menurut penilaian Taufik Adnan Amal, ternyata Mawdudi bukan termasuk seorang demokrat tulen karena tidak memandang sama sekali warga negara non-Muslim dan menafikan peran wanita di muka umum sebagaimana yang akan disinggung tersendiri. Sikap Mawdudi ini seirama dengan sikap para ulama tradisional pakistan. Lihat Taufik Adnan Amal, Islam dan Tantangan Modernitas, 63. 
bahwa tidak bisa langsung mengambil kesimpulan mengenai suatu jabatan khalifah dalam konteks politik yang secara otomatis diberikan oleh Allah hanya kepada umat Islam, termasuk mereka yang hanya beriman dan tidak berprestasi.

Selain itu, bila dilihat dari sisi realitas ekonomi dan teknologi khususnya, umat Islam sekarang masih banyak bergantung kepada karya, produksi, dan pelayanan dari negara-negara yang bukan Islam. Dari sisi realitas sosial dan kedisiplinan atau ketertiban dalam mengelola kehidupan yang ideal, ternyata umat Islam juga masih tertinggal jauh dari bangsa-bangsa non-Muslim itu.

\section{c) Negara Islam dan Gender}

Pendapat Mawdudi di atas tampaknya mudah dapat dipahami, bahwa kekhalifahan itu tidak hanya terbatas pada orang laki-laki Islam tetapi juga mencakup wanita Islam. Namun mengapa kemudian Mawdudi sendiri membatasi atau bahkan menafikan peran wanita ketika berhadapan dengan masalahmasalah politik secara lebih khusus. Jadi, wanita-wanita Islam tidak boleh duduk dalam Majelis Shura atau badan legislatif/Dewan Rakyat dan memangku jabatan-jabatan penting dalam pemerintah, seperti menteri atau direktur suatu departemen. ${ }^{47}$ Yang lebih 'janggal' lagi, ketika Fatimah Jinnah, adik perempuan pemimpin agung pakistan, yakni Muhammad Ali Jinnah, mencalonkan diri untuk jabatan presiden Pakistan pada tahun 1964 ${ }^{48}$, Mawdudi tidak hanya memberikan fatwa untuk mendukungnya tetapi juga menyertai calon presiden wanita itu berkampanye ke pelosok negeri. Hal ini dengan jelas

\footnotetext{
${ }^{47}$ Dalam hal ini, Mawdudi berpijak, pada penafsiran literal ayat 34 surat al-Nisa ; Dari sini, ia berpendapat bahwa dalam Islam terdapat suatu distribusi fungsional antara laki-laki dan wanita. Dan menurut distribusi tersebut lapangan politik dan pemerintahan merupakan bidang yagn menjadi tanggung jawab kaum lelaki. Lihat Taufik Adnan Amal (dalam catatan kaki), Islam dan Tantangan Modernitas, 63

${ }^{48}$ Tahun tersebut menurut Munawir Sjadzali. Lihat Munawir Sjadzali, Islam dan Tata Negara, 174; Idem, Ijtihad Kemanusiaan, cet. I (Jakarta: Paramadina, 1997), 7. Sedangkan menurut Taufik, disebutkan tahun 1965. Lihat Taufik Adnan Amal (dalam catatan kaki), Islam dan ..., 63.
}

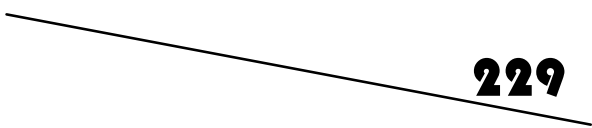


menunjukkan suatu "kejanggalan" atau katakanlah "penyimpangan" dari doktrin politiknya. Dan merupakan "tamparan"-demikian ungkapan Munawir-yang telak bagi Mawdudi dan ulama yang sependapat dengannya, bahwa justru di Pakistan sendiri jabatan Perdana Menteri diduduki oleh wanita. ${ }^{49}$

\section{d) Tiga Pilar Pelaksana Negara (Legislatif, Eksekutif, dan Yudikatif) dan sistem Pemilihannya serta Bagaimana Cara Pemecatannya bila Terjadi Penyelewengan}

Menurut Mawdudi, kekuasaan negara dilaksanakan oleh tiga badan tersebut di atas atau yang lazim disebut Trias Politika ala Montesqu. Siapapun tahu dari kalangan terpelajar, bahwa sistem itu adalah produk dari pertumbuhan politik di Barat yang secara keras ditolaknya. Kalau merujuk pada ajaran dan akar sejarah Islam, ternyata tidak ditemukan gagasan mengenai Trias Politika itu. Pada masa al-Khulafa' al-Rashidun, para khalifah merupakan penguasa tertinggi dan tunggal, didampingi sejumlah sahabat senior sebagai penasihat dengan cara yang tidak pernah dilembagakan. Para khalifah juga sekaligus bertindak sebagai hakim, meskipun tidak jarang mereka menunjuk orang-orang tertentu untuk melaksanakan kekuasaan kehakiman atas nama khalifah di wilayah-wilayah luar Madinah. Pemisahan tugas kehakiman dari jabatan Kepala Negara baru mulai dirintis semasa dinasti Umawiyah yang oleh Mawdudi ditolak untuk dijadikan contoh bagi kehidupan kenegaraan yang Islami. ${ }^{50}$

Demikian pula, pula Mawdudi menjadikan sistem politik Islam yang paripurna tanpa harus melihat kepada sistem Barat. Tetapi ketika sampai pada persoalan bagaimana cara memilih Kepala Negara dan anggota-anggota Majelis Shura, dia menyerahkan sepenuhnya kepada umat Islam untuk menempuh jalan yang terbaik sesuai dengan situasi dan kondisi yang ada,

${ }^{49}$ Munawir Sjadzali, litihad Kemanusiaan, 7.

50Munawir Sjadzali, Islam dan Tata Negara, I74- 175. 
Islam tidak mencontohkan cara tertentu untuk itu. Sementara itu, Mauwdudi juga tidak menyatakan pendapatannya secara eksplisit tentang masa jabatan Kepala Negara untuk waktu tertentu atau untuk seumur hidup. Munawir menilai sikap ini sebagai sikap yang dirasakan 'ganjil' dari seorang pemikir politik Islam pada akhir abad 20 itu. ${ }^{51}$ Menurut Munawir dan penulis sependapat dengannya, bahwa pembatasan masa jabatan untuk Kepala Negara merupakan salah satu jalan yang efektif untuk menghentikan penyelewengan seorang penguasa. seorang Kepala Negara, sehabis masa jabatannya, dapat dipilih kembali. Namun bila ternyata kepemimpinannya selama menjabat tidak menguntungkan rakyat banyak maka setelah habis masa jabatannya, rakyat dapat memilih pemimpin yang lain. ${ }^{52}$

Mawdudi menyatakan, bahwa bila Kepala Negara tersebut menyeleweng atau bisa dikatakan menyalai sumpah jabatannya dan gagal dalam melaksanakan amanat umat, dia dapat dipecat oleh umat. Tetapi sebagaimana al-Mawardi yang hidup pada abad 19, Mawdudi tidak menjelaskan tentang bagaimana cara memecat kepala negara, oleh siapa atau lembaga mana. ${ }^{53}$

\section{e) Gagasan Melarang Memilih Orang-orang yang Mencalonkan Diri dan Pendirian Partai-partai}

Satu keanehan lagi dari gagasan politik Mawdudi, bahwa ia membenarkan pengisian jabatan Kepala Negara dan anggotaanggota Majelis Shura melalui pemilihan, tetapi ia tidak menyetujui atau bahkan melarang rakyat untuk memilih kandidat yang sengaja mencalonkan diri atau yang berupaya menduduki jabatan-jabatan tersebut. Dan tidak memperbolehkan pula kandidat-kandidat tersebut melakukan kampanye, "Suatu praktek yang bertentangan dengan Islam". Kalau begitu dengan cara yang bagaimana agar lebih demokratis?. Penulis sendiri atau bahkan

\footnotetext{
${ }^{51}$ Ibid, 175.

${ }^{52} \mathrm{lbid}$.

${ }^{53}$ bid.
}

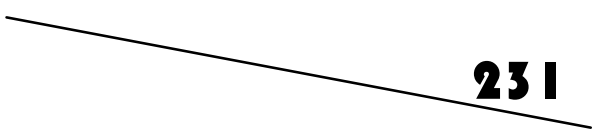


mungkin pembaca sulit menemukan jawabannya dan kiranya Mawdudi juga tidak tahu cara apa yang harus ditempuh untuk memilih Kepala Negara dan anggota-anggota Majelis Shura, bila tetap tidak dibenarkan mencalonkan diri dan berkampanye.

Dalam kehidupan politik modern, seorang kandidat atau calon untuk satu jabatan diharapkan memberitahukan kepada para calon pemilih tentang program-program, kesanggupan dan janjinya kalau dia nanti terpilih, serta identitas atau jati dirinya. Memang dapat terjadi seorang calon berhasil menarik perhatian dan dukungan para calon pemilih melalui kepandaiannya membual atau merayu, bahkan sampai mengobral janji disertai membagi-bagi hadiah. Hal tersebut sering kali terjadi di negara yang masih baru dalam kehidupan berdemokrasi. Tetapi makin meningkat kedewasaan politik rakyat, kalau seorang calon berhasil terpilih dan selama masa jabatannya tidak memenuhi janji-janji yang pernah diobralnya pada kampanye pemilihan umum yang lalu maka dia tidak akan dipilih lagi. Dalam hubungan ini, menurut Muhammad Abduh, sebagaimana yang dikutip oleh Munawir Sjadzali, hendaknya perubahan politik dan pemberian hak berpolitik kepada rakyat dilaksanakan secara gradual dan bertahap. Jangan langsung dibentuk Dewan Perwakilan Rakyat melalui pemilihan umum yang bebas sebelum rakyat cukup dewasa dalam berpolitik. Sebab rakyat yang masih buta dalam berpolitik akan mudah menjadi korban dari bualan janji kosong para politisi yang akibatnya Dewan Perwakilan akan dipenuhi oleh "petualang-petualang politik". ${ }^{44}$ Dengan kata lain, Mawdudi menolak sistem pencalonan dan mengutuk praktek kampanye berdasarkan pengamatannya terhadap gejala-gejala yang sifatnya sementara, yakni selama demokrasi belum berkembang. Kenyataannya, sejak berdirinya Pakistan, Mawdudi dan Jama't-i Islami aktif berkampanye untuk "menjual" program empat butirnya. Dan yang cukup menarik juga, Mawdudi

${ }^{54}$ Ibid., 176. 
mendiamkan tentang Hadis yang berisi keharusan Kepala Negara dari suku Quraysh. 55

Masih dalam gagasan anehnya Mawdudi, bahwa ia tidak membenarkan mengenai pembentukan kelompok-kelompok atau partai-partai politik dan hendaknya masing-masing anggota Majelis berbicara atas nama pribadi. Tetapi kalau tetap dibentuk partai maka boleh dibentuk terbatas hanya satu partai, yaitu Partai Pemerintah atau Partai Kepala Negara. ${ }^{56}$ Namun dalam realitas kehidupan politik, ternyata keanggotaan yang bersifat perorangan itu memperlemah Dewan Perwakilan ketika menghadapi pemerintah dan sebaliknya mempermudah Kepala Negara atau pemerintah untuk "mengatur" Dewan Perwakilan. Selain itu juga, merupakan fitrah manusia, bila orang-orang yang sejalan pikirannya dan sependirian cenderung untuk mengelompokkan diri, suatu proses sosial yang tidak mungkin ditahan. Dan bila yang diizinkan hanya satu partai yang tak lain partai pendukung Kepala Negara berarti negara itu menganut sistem totaliter. Namun dengan kehadiran lebih dari satu partai dalam Dewan Perwakilan justru akan mempertajam pengawasan terhadap jalannya pemerintahannya dan lebih menguntungkan kepentingan rakyat sebagai pemegang tertinggi kedaulatan sekaligus yang memberi amanat.

\section{f) Syari'at Islam: antara Statis dan Dinamis}

Menurut Mawdudi, sebagaimana telah di singgung, bahwa bila sudah terdapat nash al-Qur'an atau Hadis yang jelas teksnya tanpa harus diketahui terlebih dahulu mengenai asbab al-nuzul atau asbab al-wurud-nya maka siapapun tidak boleh bergeser dari nash tersebut. Baik Majelis Shura, maupun rakyat tidak dibenarkan mengubah satu kata pun dari nash itu.

Menurut penulis, sungguh ini merupakan pola pemikiran yang dapat dikatakan "terbelakang". Sementara para sarjana

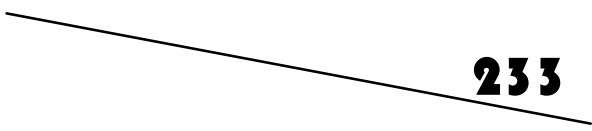


hukum Islam terkemuka dari berbagai zaman tidak ditemukan suatu pendapat yang sekaku atau sesempit itu. Abu Yusuf, salah seorang penerus mazhab Hanafi yang pernah menjabat Ketua Mahkamah Agung di Baghdad, dua belas abad yang lalu menyatakan, bahwa suatu nash yang dalam proses histrorisnya ditetapkan berdasarkan adat, lalu adat itu telah berubah oleh sebab perubahan masa maka hukum yang terkandung dalam nash tersebut menjadi gugur. ${ }^{57} \mathrm{Najm}$ al-Din al-Tufi $(673-716 \mathrm{H})$, seorang ahli hukum Islam terkemuka dari mazhab Hanbali, lebih dari tujuh abad yang lalu dengan tegas menyatakan, bahwa dalam hal hukum yang menyangkut persoalan-persoalan sosialkemasyarakatan (mu'amalat) kalau terjadi kontradiksi antara kepentingan masyarakat (maslahah 'ammah) dengan nash atau ijma' maka kepentingan masyarakat itulah yang diprioritaskan. ${ }^{58} \mathrm{Al}-$ Shatibi (w. 790 H/1388M.) dari Mazhab Maliki yang juga dikenal dengan teori maslahat mursalah-nya, dalam tesisnya menyatakan, bahwa tujuan utama ditetapkannya suatu hukum oleh Shari' adalah semata-mata untuk kemaslahatan manusia. Untuk ini, merupakan suatu "kemestian" dalam syari'at, bila selalu mempertimbangkan dan memperhatikan maqasid al-syari'ah. ${ }^{59}$ Yang menjadikan penulis lebih heran lagi, Mawdudi sendiri menganjurkan untuk menerjemahkan kitab al-Muwafaqat itu dalam rangka pemahaman tentang falsafah hukum Islam. ${ }^{60}$ Demikian

\footnotetext{
${ }^{57}$ Ibid. 177

${ }^{58}$ Namun sebelumnya harus melalui proses al-jam' (penggabungan antara yang kontradiksi dengan cara melihat aspek historis suatu dalil dari sisi usul fikihnya). Bila tidak mungkin, baru dilakukan tarjih. Lihat 'Abd al-Wahhab Khallaf, Masadir al-Tashri' al-Islami fi ma la Nassa fih, cet. 3 (Kuwait: Dar al-Qalam, 1972), 98; al-Tufi dinilai terlalu radikal oleh sebagian ulama, namun setelah diteliti, motif apa yang melatarbelakangi pendapatan itu, ternyata dalam mengaplikasikan maslahah ammah ini diterapkan metode al-takhsis wa al-bayan (nash menghendaki sesuatu yang khusus lalu hal-hal yang tidak termasuk di keluarkan dengan disertai penjelasan yang memadai), bukan metode al-tatil wa al-iftiat (pengabaian sama sekali keberadaan nash). Lihat Husayn Hamid Hassan, Nazariyyat al-Maslahah fi al-Fiqh al-Islami (Beirut: Dar al-Nahdah al'Arabiyyah, 197I), 534.

${ }^{59} \mathrm{Al}$-Shatibi, al-Muwafaqat fi Usul al-Shari'ah, cet. I, jilid 2 (Beirut: Dar al-Ma'rifah, 1994), 339.

${ }^{60}$ Mawdudi juga menyebut kitab-kitab yang lain yang juga ia anjurkan untuk diterjemahkan, seperti Usul al-Ahkam oleh ibn Hazm, al-Ihkam fi Usul al-Ahkam oleh al-Amidi. Hujjatullah al-Balighah oleh Shah Waliyyullah al-Dahlawi.
} 
pula Muhammad 'Abduh, seorang tokoh pembaharu Islam yang hidup pada akhir abad 19 M. menyatakan, bahwa kalau terjadi pertentangan antara nash dan nalar maka yang dimenangkan adalah nalar. ${ }^{61}$ Bahkan dua mufassir terkemuka zaman modern, yaitu Ahmad Mustafa al-Maraghi dan Muhammad Rashid Rida berpendirian, bahwa hukum-hukum itu diundangkan demi memenuhi kepentingan manusia sedangkan kepentingan manusia itu dapat berbeda karena perbedaan zaman dan tempat. Oleh karena itu, bila kemudian zaman telah berubah dan hukum tersebut tidak sesuai lagi maka lebih bijaksana kalau hukum tersebut ditarik dan diganti dengan hukum baru yang lebih sesuai dengan situasi baru dilihat dari segi kemaslahatan rakyat banyak. ${ }^{62}$

\section{g) Batasan Universalisme Sistem Politik Islam}

Menurut Mawdudi, sistem politik Islam adalah universal yang tidak mengenal batas dan ikatan geografis, bahasa, dan kebangsaan. Namun bila hal ini dihadapkan pada sejarah, termasuk sejarah kontemporer, bahwa ternyata tidak satu pun ditemui suatu fakta yang benar-benar sesuai dengan ungkapan "universal" yang tiada batas itu. Dan sebaliknya, solidaritas kelompok yang didasarkan atas persamaan wilayah tempat tinggal, persamaan bahasa, budaya, dan bangsa serta etnik atau yang lebih dikenal dengan "nasionalisme" banyak dijumpai di sana-sini yang memang ternyata lebih kuat ikatannya. Al-Qur'an sendiri ternyata mengakui realistis ini sebagai sesuatu yang wajar dan pantas dihormati sebagaimana yang tertera dalam surat alHujurat ayat 49. Menurut Munawir, yang bisa ditangkap dari ayat tersebut berkenaan dengan pembahasan ini, bahwa dengan berdasarkan persamaan agama semata ternyata tidak mampu mengalahkan solidaritas kelompok yang berdasarkan persamaan etnik dan persamaan kepentingan wilayah. ${ }^{63}$ Dalam hal ini, dapat

\footnotetext{
${ }^{61}$ Munawir Sjadzali, Islam dan Tata Negara, 177.

${ }^{62}$ lbid., 177-178.

${ }^{63} \mathrm{lbid}$.
}

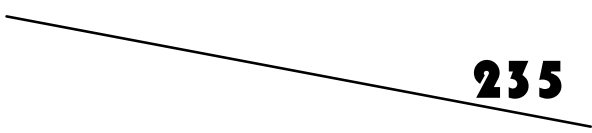


dilihat dengan jelas, yakni kegagalan mempertahankan keutuhan Pakistan yang pada tahun 1947 yang didirikan bersama-sama oleh umat Islam. Rakyat Pakistan Timur dari etnis Bengali merasa diperlakukan kurang adil oleh pemerintah pusat. Akhirnya mereka memberontak dan berhasil melepaskan diri dan jadilah Negara Banglades. ${ }^{64}$ Dalam hubungannya dengan pembagian warga negara, yang Muslim dan yang non-Muslim (dhimmi) dengan konsekuensi masing-masing hak mereka yang dibedakan, juga perlu dipertanyakan, yakni apakah yang demikian ini relevan dengan universalisme Islam?.

\section{Penutup}

Sosok Mawdudi merupakan seorang figur sekaligus pejuang hidup di wilayah subkontinen (India dan Pakistan) yang begitu gigih dan sangat tekun untuk menyuguhkan Islam sebagai suatu sistem komprehensif bagi kehidupan manusia. Tidak ada satupun pembicaraan yang lepas dari ajaran Islam, mulai dari legal-formalspesifiknya sampai nilai-nilai subtansi suatu persoalan, semuanya ada di dalam Islam, termasuk pembicaraan tentang konsep negara Islam yang sebagaimana telah disinggung secara panjang lebar. Kalau dibandingkan dengan tokoh-tokoh yang kurang lebih semasa dengannya, seperti Shah Waliyyullah, Sir Sayyid Ahmad Khan, Amir Ali, Muhammad Iqbal, Fazlur Rahman, al-Nadwi, dan lain-lain, pemikiran Mawdudi hadir di hampir seluruh aspek kehidupan dan disiplin ilmu, mulai dari yang religius sampai ke bidang yang dianggap sekuler, dan dari persoalan nilai sampai ke hal-hal teknis-operasional, semuanya ia tulis secara sistematismetodologis dalam karya-karyanya. Sehingga tidak mengherankan, jika seorang orientalis kelas kakap, Wilfred C. Smith dalam bukunya Islam in Modern History, menyatakan bahwa Mawdudi adalah seorang pemikir Islam yang paling sistematik dari kawasan Indo-Pakistan. Namun demikian, dibalik 
gagasannya atau pemikiran-pemikirannya tidak lepas dari kekurangan-kekurangan. Mawdudi tetap berdiri kokoh di atas pemikiran-pemikirannya yang patut untuk dihormati dan di kenang sepanjang masa.

\section{Daftar Rujukan}

Ahmad, Khursid dan Zafar Ishaq Ansari. “Mawlana Sayyid Abdul A'la Mawdudi, an Introduction to His Vision of Islam and Islamic Revvial". dalam Islamic Prepectives Studies in Honour of Mawlana Sayyid Abdul A la Mauwdudi. Ed. K. Ahmad dan Z.I Ansari. Jeddah: The Islamic Foundation U.K in Association with Saudi Publishing House, t.t.

Ahmad, Istiaq. The Concept of an Islamic State. New York : St. Martin's Press Inc, 1987.

Ali, A. Mukti. Alam Pikiran Islam Modern di India dan Pakistan. cet. 3. Bandung: Mizan, 1996.

Amal, Taufik Adanan. Islam dan Tantangan Modernitas (Studi atas Pemikiran Hukum Fazlur Rahman). cet. 5. Bandung: Mizan, 1994.

Choueiri, Youssef M. Islamic Fundamentalism. London: The Castlefield Press Ltd, 1990.

Departemen Agama Republik Indonesia (DEPAG R.I). Ensiklopesi Islam di Indonesia. jil. 2. Jakarta: Proyek Peningkatan Prasarana dan Sarana Perguruan Tinggi Agama, 1992/1993.

Enayat, Hamid. Modern Islamic Political Throught. London: The Macmillan Press, 1982.

Esposito, John L. Islam dan Politik. cet. 1. ter. M. Joesoef Souyb. Jakarta: PT Bulan Bintang, 1990.

Hassan, Husayn Hamid. Nazariyyat al-Maslahah fi al-Fiqh al-Islami. Beirut: Dar al-Nahdah al-'Arabiyyah, 1971.

Jameelah, Maryam. Who is Maudoodi?. edisi 3. Lahore: Mohammad Yusuf Khan \& Sons, 1983.

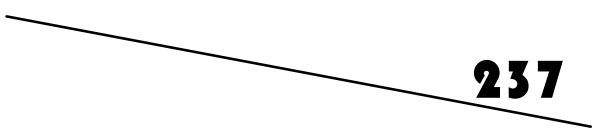


Khallaf, 'Abd al-Wahhab. Masadir al-Tashri' al-Islami fi ma la Nassa fih. cet. 3. Kuwait: Dar al-Qalam, 1972.

Lapidus. A History of Islamic Socities. cet. 4. Cambridge University Press, 1991.

al-Mawdudi, Abu al-A'la. Khalifah dan Kerajaan. cet. 6 ter. M. alBaqir. Bandung: Mizan, 1996.

. The Islamic Law and Constitution. Edisi 6 ter. dan ed. Khurshid Ahmad. Lahore: Islamic Publications LTD., 1977. . "Ajaran-ajaran al-Qur'an tentang Ekonomi dan Politik". dalam Esensi al-Qur'an (Filsafat, Politik, Ekonomi, Etika). cet. 8. Penyunting M.M. Syarif. ter. Ahmad Muslim. Bandung: Mizan, 1997.

Nasr, Seyyed Vali Reza. "Mauwdudi, Sayyid Abu al-A'la. dalam The Oxford Encyclopedia of the Modern Islamic World. vol. 3. ed. John L. Esposito, et. Al. New York: Oxdord University Press, 1995.

"Mauwdudi dan Jamaat'-i Islami: Asal-usul, Teori dan Praktik Kebangkitan Islam". Dalam Para Perintis Zaman Baru Islam. cet. 2.ed. Ali Rahnema. ter. Ilyas Hasan. Bandung: Mizan, 1996.

Nasution, Harun. Pembaharuan dalam Islam, Sejarah Pemikiran dan Gerakan. cet. 9. Jakarta: PT Bulan Bintang, 1992.

Piscatori, James P. Islam in a World of Nation States. Cambridge: Cambridge University Press, 1988.

Rais, Amien. Cakrawala Islam Antara Cita dan Fakta. cet. Bandung: Mizan, 1991.

Rosenthal, Erwin I.J. Islam in the Modern National State. London: Cambridge University Press, 1965.

Sjadzali, Munawir. Islam dan Tata Negara (Ajaran, Sejarah, dan Pemikiran). edisi 5. Jakarta: UI Press, 1993. . Ijtihad Kemanusiaan. cet. 1. Jakarta: Paramadina, 1997.

Smith, Wilfred Cantwell. Modern Islam in India (a Social Analysis). New Delhi: Usha Publication, 1979. 
al-Shatibi. al-Muwafaqat fi Usul al-Shari'ah. cet. 1. Jilid 2. Beirut: Dar al-Ma'rifah, 1994.

Tahhan, Mustafa Muhammad. Model Kepemimpinan dalam Islam (Studi Tokoh Pergerakan Islam Kontemporer). cet. 1. ter. Musthofah Maufur. Jakarta: Robbani Press, 1997.

Tim penyusun Pustaka-Azet Jakarta. Leksikon Islam. jilid 2. Jakarta: PT Pustazet Perkasa, 1988. 